\title{
Marianna Fotaki
}

ORCID: https://orcid.org/0000-0002-2130-6936

University of Warwick ${ }^{1}$

\section{Refugee and forced migrants are not welcome in Europe's diminished welfare states}

\begin{abstract}
The recent arrivals of refugees from the Middle East fleeing war and persecution, and forced migrants escaping poverty, mostly from Asia and Africa, have fundamentally challenged European states' commitment to solidarity with these vulnerable populations seeking protection. Researchers have identified a range of social and individual factors that may facilitate or impede societies' willingness to receive refugees and migrants. However, less attention has been devoted to how their reception may be linked with diminished provision of public services for citizens and declining welfare states in many countries in Europe. This article considers how the ascendance of the neoliberal ideology and its key shifts in public policy contributed to a growing sense of insecurity and precarity in industrialized countries over recent decades and has affected people's willingness to assist and accept them. It brings together insights from a variety of disciplines to better understand social policy developments and its relation to refugee and forced migration. It concludes that a feminist psychosocial conception of relationality provides a basis for rethinking our approaches to these important issues by politicizing the ethical obligation to protect the lives of unknown others.
\end{abstract}

Key words: refugee, forced migration, welfare state, relationality, Judith Butler

1 Correspondence: Marianna Fotaki, University of Warwick Warwick Business School, Coventry, Scarman Road CV74AL, author's email address: Marianna.Fotaki@wbs.ac.uk. 
We are now witnessing perhaps the highest recorded levels of displacement in world history. In 2015, an unprecedented 68.5 million forced migrants were seeking new lives, including nearly 25.4 million refugees, half of them under the age of 18 (UNHCR, 2015). The arrival of over a million refugees into the European Union, mainly from Syria, Iraq, and Afghanistan, over a short period of a few months in 2015 highlighted the urgency and magnitude of this phenomenon. While the arrivals have much decreased since then reaching less than 130000 in 2019 (International Migration Office, 2020), there is a polarization of opinions with growing mobilizations of anti-migration attitudes across Europe (Rea et al., 2019). Both refugees from the Middle East fleeing war and persecution, and forced migrants escaping poverty, mostly from Asia and Africa, are often considered as fundamentally challenging European states' notions of sovereignty, national integrity, and cohesion (Fotaki, 2019a).

Researchers have identified a range of social and individual factors that may facilitate or impede societies' willingness to receive refugees and migrants, falling into the broad categories of economic, security-related, cultural and integration threats (Dempster \& Hargrave, 2017; Esses et al., 2017). In addition to perceiving refugees and migrants as threats to the economy and security, anxiety is often attributed to concerns around globalization and multiculturalism (Dempster \& Hargrave, 2017). However, less attention has been devoted to how their reception may be linked with diminished provision of public services for citizens and declining welfare states in receiving countries. This is a potentially important factor influencing public attitudes to newcomers in local communities, neighborhoods, and cities (WEF, 2017), especially when they compete or are perceived to be competing for access to scarce or decreasing resources such as publicly funded education, health, transportation, and public safety systems (Hunter, 2016; Papademetriou \& Banulescu-Bogdan, 2016).

This article considers how, following the ascendance of the neoliberal ideology, key shifts in public policy, which have contributed to a growing sense of insecurity and precarity in industrialized countries over recent decades, may have affected people's willingness to assist and accept refugees and forced migrants. This, it is argued, is a result of a long trend toward market governance in all spheres of public policy, and the discourse of consumerism replacing the notion of dependency (Fotaki, 2019a). In the UK and Sweden, for instance, until the late 1980s public health and social services were publicly financed and designed to ensure equitable access by all citizens, based on need rather than ability to pay. The introduction of the consumerist market logic of the internal market (the UK) or public competition (Sweden), under the guise of empowerment and choice, marked a departure from the post-war values of egalitarianism and universalism (Fotaki, 2011; Fotaki \& Boyd, 2005).

The privatization of public services and their transformation into consumerist market commodities (Fotaki, 2011, 2014) are consequences of the financialization of all forms of social life and the shifting of risk onto individuals (Haiven, 2014). Over time, outsourcing of public services to the market has gradually been combined with reductions in the scope of service and benefit provision, which worsened under the protracted austerity following 
the 2008 global financial crisis (GFC). Taken together, these have produced growing numbers of new poor and people fending off various forms of encroaching dispossession in industrialized countries in the global North (Sassen, 2014).

Under conditions of manufactured scarcity resulting from policy choices promoting liberalization and privatization of the welfare state, refugees and involuntary migrants are seen as competitors for ever-decreasing resources in times of increasing need. This is partly because the governments of advanced economies appear unable and unwilling to take a coordinated approach to addressing refugees' needs (Fine, 2019), and partly because they actively stoke their constituents' resentment of destitute 'others'. At the same time, the magnitude of refugees' healthcare needs, placing additional demand on the country's stretched national health systems (Fotaki, 2019b). For instance, it has only recently been recognized in Germany, that at least half of all refugees suffer from some form of definable mental illness (Hunter, 2016).

This article will examine how the ruling elites in selected European Union countries (including politicians and the media) may contribute to casting the dispossessed refugees and migrants as perils to the social order (Berry et al., 2015). They are often presented as threatening figures, through various ideological discourses (e.g., by deploying racialized tropes), and are portrayed as utterly and irreconcilably different from ourselves (Fotaki, 2017a). These issues are examined in three countries: Poland, Sweden, and the UK, representing different social policy models and degrees of reliance on market mechanisms in delivering these policies. The argument offered is that the introduction of New Public Management in the UK and Sweden with market competition and privatization of public services as key planks of such policies, has led to their retrenchment in scope and quality while diminishing the publicness of public services (Haque, 2001). It is also suggested that in casting refugees as threat to the already reduced welfare state which is unable to meet the needs of its citizens as is the case in the UK, or redirecting citizens' attention from the breaking of generational welfare state contract as is the case of Sweden (Widmalm, 2018), allows governments to abdicate responsibility for their failure to protect the most vulnerable groups. They often mobilize fear and disgust towards the dispossessed newcomers to distance the not-yet-dispossessed of developed countries from the all-too-human suffering (Fotaki, 2019a), while obscuring their own culpability for the let-down. This reduces solidarity with uprooted people and increases migrants' exploitability (Cholewinski \& Taran, 2009), while detracting the citizens of affluent European countries from holding politicians to account for policy choices that lead to insufficient public services. In Poland's transition to capitalism after 1989, the neoliberal dismantling of the pre-existing welfare state, which remained unchallenged by most parties until the ascension to power of the nationalist right in 2015 (Konat, 2019), led to soaring unemployment and mass emigration. The incoming populist right-wing party capitalized on this discontent by offering generous social benefits while appealing to and activating fear and apprehension of unknown strangers in their constituencies (Krzyżanowska \& Krzyżanowski, 2018). Framing the refugee arrivals as a 'migration crisis' (Cieślińska \& Dziekońska, 2019), can explain the negative attitude towards immigration in Poland, by 
a part of society fearing the potential reversal of a significant increase in social spending coinciding with their arrival.

The remainder of this article briefly discusses historical instances of hostility faced by refugees and newcomers, and contrasts these with welcoming attitudes to explain how such contrasting reactions arise. The explanatory framework adopts a multidisciplinary perspective, focusing on neoliberal policy shifts and ideological discourses in the media and politics to describe shifts in public attitudes and ambivalence toward needy and dispossessed populations in selected European countries. The article concludes by proposing a feminist psychosocial conception of relationality to politicize the ethical obligation to protect the lives of unknown others, and offers this as a basis for rethinking refugee and forced migration policies.

\section{Changing attitudes to migration and refugees}

Migration has occurred throughout history, as humans have fled war, persecution, and extreme destitution. More recently, forced migration has been an integral part of North-South relationships and is closely linked with the current processes of global social transformation (Castles, 2003; Castles \& Miller, 2009), encompassing armed struggles, local wars, and even genocides (Malkki, 1995).

The concept of the refugee and the obligation to protect refugees arose in the aftermath of World War Two, when practices for managing displaced people became standard and global (Malkki, 1995). This emerged not only from the post-war realities of mass displacement, but also from the pre-war failure to prevent stateless people from becoming 'rightless' (Arendt, 1951). Treating refugees as migrants in the 1920s and 1930s failed to ensure their protection from persecution because their admission depended entirely on economic criteria (Long, 2013). Separating refugees from migrants stipulated in the 1950s legislative acts of the Geneva Convention, by providing refugees with an exceptional right to cross borders and claim asylum, helped to address this protection gap. However, it no longer holds true that immigrants constitute an economic form of migration and refugees a political one (Hein, 1993), given that the 'refugee' and 'migrant' categories are often blurred in practice (Long, 2013). Whether or not they meet the official definition of refugees, many are escaping dire conditions that pose a threat to their survival (Betts, 2010). This article considers refugees as defined by the Geneva Convention (UNHCR, 1951), as well as the broader category of forced migrants and various forms of involuntary migration that are not forced but caused by unfavourable situations (King \& Lulle, 2016).

Every migration and refugee situation is embedded in a specific historical and political context (Malkki, 1996; Reinisch, 2015) that eschews universal typologies. Malkki (1996) specifically argues that abstract consideration of the typical refugee situation silences people's lived experiences and impedes effective policy implementation aimed at addressing their needs. Her anthropological research in Hutu camps in Tanzania in 
the early 1990s demonstrates how these refugees saw themselves as a nation, enabling them to reclaim their future home in Burundi. This is contrasted with the refugee as a passive object of humanitarian intervention, a characterization on which international aid organizations relied in their daily work with this group of people (Malkki, 1996).

Nor should receiving communities' attitudes to migration be viewed out of context, as they differ according to the characteristics of arriving populations, even within the same country or place. Cieślińska and Dziekońska (2019) compare two relatively recent but different groups of refugees arriving in Białystok city in Eastern Poland from Armenia in the 1990s and Chechnya in the early 2000s. They conclude that although the first group did not receive refugee status, their presence was 'tolerated', they integrated faster, and they were on the whole better received by the local community than the latter group, which remains isolated in the ghettoized conditions of a refugee centre, even though their rights are legally recognized. The authors also contend that the characteristics of these earlier refugee arrivals from Armenia and Chechnya differ from those of the recent 'crisis' of 2015-16 (Cieślińska \& Dziekońska, 2019).

Moreover, populations' and local communities' attitudes may change relatively quickly when framed through media debates (Dennison \& Dražanová, 2018) and leaders's symbolic and material support, or lack thereof. Both the language they deploy and the specific policies enacted are key. Information environments and elite rhetoric play central theoretical roles in explaining attitudes toward immigration, and especially their dynamics (Hainmueller \& Hopkins, 2014). McHugh-Dillon (2015) describes this relationship as bi-directional: while political narratives are heavily influenced by what politicians think the public feels about these issues, they also establish a backdrop against which public attitudes are formed. For instance, the discourse of economic threat (e.g., concerning job competition or fears of disintegration of the welfare state) in the media and official discourses is often collapsed together with the threat to security (Long, 2012), prompting governments' ever more aggressive reaffirmation of national borders in response to constituents' real or perceived demands. Thus, ways of thinking about migrants and migration circulating in the media and in political discourses are becoming well-established conceptualizations to legitimize one's moral stance toward the Other/'them' (Arcimaviciene \& Baglama, 2018).

How supranational bodies and international humanitarian organizations address refugee issues also impacts on public attitudes. Outsourcing responsibility for preventing arrivals into regimes with a poor track record of protecting humanitarian rights, such as Turkey and Libya, and criminalizing citizens' sea rescues (Fine, 2019) and other forms of assistance to refugees (Maccanico et al., 2018) discourages individuals from offering any help to people in need, who are stigmatized as unwanted and potentially dangerous trespassers. This has been evident in a shift in attitudes to recently arriving refugees from Syria and the Middle East to the shores of the European Union. Local communities in European countries such as Greece and Italy, the first points of entry to the EU, initially responded by actively joining forces with international networks of volunteers to address their most urgent needs (Amnesty International, 2015). However, this changed drastically 
following the controversial EU-Turkey deal (Fotaki, 2016)2 , despite instances of entire villages in Italy and Greece integrating refugees as contributors to local communities (BBC, 2017; Canal, 2017). In this initial phase, the arrival of huge numbers of refugees was also welcomed and experienced as extraordinarily positive by the public in Germany (Karakayali, 2018) and Sweden (Krzyżanowski, 2018). Nevertheless, across the EU, attitudes toward asylum and immigration have since hardened.

The reasons for this shift are multiple, and are linked to a variety of factors relating to real or perceived economic threats, changing cultural norms, crime, terrorism, and governments' capacity to manage these challenges effectively (Papademetriou \& Banulescu-Bogdan, 2016). Sudden arrivals may be destabilizing, even if the absolute number of immigrants is relatively small, especially when they outpace a country's or community's preparedness and ability to receive them. However, as Papademetriou and Banulescu-Bogdan (2016, p. II) note, 'none of these concerns on their own can explain what drives anxiety about immigration; rather, it is how they overlap and what triggers them in each context that determines public reactions'. Such was the instance of the terrorist attacks in Paris in 2015 or Brussels in 2016 (Laciak \& Segeš Frelak, 2018), and sexual assaults perpetrated in Cologne, Germany during the New Year celebrations at the end of that same year (Rea et al., 2019) acting as trigger factors for hardening of attitudes and the overturning of "welcome culture".

However, many of these developments speak to and perpetuate fears of newcomers taking away valued and/or scarce resources from host communities, which may be particularly acute in areas less accustomed to migration and where local populations are already experiencing hardship. Protracted austerity in the aftermath of the GFC transformed the domestic political landscapes of many EU countries, created a fertile ground for populist right-wing parties to scapegoat migrants and refugees by convincing electorates that they must be deterred at all costs, despite the absence of strong evidence of refugees placing strain on host countries' public resources or participating in labour with a negative effect on local populations. Macroeconomic assessments of refugees' positive impact on economic growth, and their temporary and limited adverse effects on local wages and unemployment levels (Aiyar et al., 2016) are largely ignored. For example, Legrain (2016) shows that for European countries, investing one euro in helping refugees may yield two euros in economic benefits within only five years. In evaluating the economic and fiscal effects of inflows of asylum seekers into Western Europe from 1985 to 2015, D'Albis, Boubtane and Coulibaly (2018) demonstrate that they do not harm host countries' economic performance or fiscal balance, because increased public spending on asylum seekers is more than compensated for by increased tax revenues net of transfers.

2 The original idea was to send thousands of refugees back to Turkey in a deal aimed at preventing people from trying to reach the EU by sea. In exchange, Turkey would receive $€ 6$ billion to assist the vast refugee community hosted there, Turkish nationals would be granted visa-free travel to Europe and, once the number of irregular arrivals dropped, a 'voluntary' humanitarian scheme to transfer Syrians from Turkey to other European countries would be activated (Fine, 2019; Gogou, 2017). 
Another commonly articulated fear relating generally to the arrival of migrants is that 'migration is a threat to our culture'. Yet as Tramontana (2018) argues, 'cultures however are not absolute and those in the Western World have been massively shaped by migration'. Her examples include how 'German migrants ... spread the Christmas tree', 'the Italian food brought by migrants, once despised and the object of insults such as "spaghetti bender", is now a well-recognised part of American diet', and 'Jews of Spanish and Portuguese origin, who fled religious persecution from the Netherlands, introduced fish and chips to England'. References to such positive examples point to the potential social benefits of migration, and reveal how cultures have been and can be enriched by people coming from different parts of the world.

Nevertheless, public debate about immigration into Europe continues to be fixated on the costs of receiving refugees, and is often based on xenophobic assumptions and generalizations connected with terrorism, which further distort the discussion (Arenaidé, 2017; Łaciak \& Segeš Frelak, 2018; Rea et al., 2019). Such narratives mobilize affect by evoking fears of annihilation by mass arrivals of aggressive and culturally alien newcomers bent on destroying Christian civilization and/or liberal Western ways (Huntington, 1993). What underpins these is fear for survival, in terms of various threats to life, and insufficient resources often relating to being cared for when vulnerable.

While refugee and migratory movements may be seen as fundamentally challenging European states' notions of sovereignty, national integrity, and cohesion, attitudes may differ between countries. These may relate to specific histories and memories often reveal contrasting responses by government and populace as evidenced in the case of Poland, Sweden and the UK that this article discusses. For instance, despite the anti-migration rhetoric of moral panic propagated by Poland's right-wing government (Krzyżanowska \& Krzyżanowski, 2018), concerns and fears about newcomers were, to some extent, intertwined with compassion and attempts to understand this situation (Cieślińska, 2017; Jaskułowski, 2019). However, orchestration by Poland's right-wing populist 'Law and Justice' (PiS) party of strong anti-immigration and anti-refugee rhetoric across the Polish public sphere has also played a pivotal role in enabling xenophobic and blatantly racist sentiments to be countenanced in wider Polish public discourse and society (Krzyżanowska \& Krzyżanowski, 2018). The case of Poland demonstrates the power of elite's discourse to mobilize moral panic, since Poles learned about the European migration crisis mainly through mass media, and then began to fear the perceived consequences of accepting immigrants and refugees of different religions and cultures (Laciak \& Segeš Frelak, 2018; Cieślińska \& Dziekońska, 2019). In addition to the common trope of alleged threats to the welfare state posed by refugees and migrants reiterated in many other EU countries, there was a unique and specific theme of an impending crisis that Poland could not afford to countenance (Cieślińska \& Dziekońska, 2019). Whether real or imaginary, this linking of migration with crisis not only spoke to the recent and past experiences of many Polish citizens across generations, but also represented a significant break with the traditionally strong (and mostly positive) emphasis on emigration in the Polish collective imagination (Krzyżanowska \& Krzyżanowski, 2018). 
The case of the UK, which has received very few refugees or forced migrants, is even more drastic, as this issue was skillfully and dishonestly used to manipulate public opinion to influence the outcome of Brexit. A recent study by Wadsworth, Dhingra, Ottaviano, and Van Reenen (2016) shows that areas of the UK with large increases in EU immigration did not suffer greater reductions in UK-born workers' jobs and pay. In fact, large falls in wages after 2008 were due to the GFC and weak economic recovery, not to immigration. Nevertheless, media coverage in the UK was the most negative and most polarized, with Britain's right-wing media being uniquely aggressive in its campaigns against refugees and migrants (Berry et al., 2015). This toxic rhetoric was legitimized by David Cameron, the UK's prime minister, in his dehumanizing reference to refugees as 'swarms of people' (Taylor et al., 2015). Portrayal of refugees and forced migrants as carriers of threatening diseases rather than as human beings with intrinsic moral value was also expressed in an exaggerated statement bordering on hysteria by Poland's de facto leader, Jarosław Kaczyński (Krzyżanowska \& Krzyżanowski, 2018). On the other hand, the Swedish press was the most positive toward refugees and migrants; nevertheless, discourses on the contraction of the welfare state prompted by refugee arrivals also emerged in Sweden. For instance, fear of refugees and migrants, stoked by the Sweden Democrats, a party with neo-Nazi roots, seems to have grown in the context of the decaying welfare state (Nilsson, 2018).

The article argues, that although the retrenchment of welfare provision and the outsourcing of public services to the market is unrelated to their arrival, but rather exposes the failure of the neoliberal governance. For instance, the welfare system built to support Sweden's citizens has declined over time. This was largely a result of the decrease in public funding and the gradual privatization of social care services over the last decades. The belief that social policy could be used as a tool for social transformation in post-war welfare states has been increasingly challenged and ultimately rejected. In the aftermath of the neoliberal drive for efficiency and marketization of public services (Widmalm, 2018), the state is now failing to provide dignified care for its elderly. Thus, despite diametrically opposite reactions in Sweden and Germany, whose governments welcome and offer support to refugees, this has not removed tensions and negative attitudes toward refugees as potential competitors for scarce public resources and access to welfare services.

The governments of some other affluent European states that might have assisted refugees (such as the UK) fear that local services would be unable to cope, even though the fragility of these services is often entirely due to their own governments' cost cutting. They refuse to accept immigrants, and even genuine refugees, amid growing support for fringe political parties proposing exit from supranational institutions and the end of foreign aid (Coppola, 2018). On the other hand, former socialist countries in Eastern Europe, such as Poland, are still rebuilding their residual welfare states after the radical systemic transformation of the early 1990s, and see refugees as a potential threat to their new-found stability and a harbinger of multicultural tensions. Such developments seem to confirm Offe's (2018) contention that democracy cannot survive without the welfare state, which ensures universal provision of such services, and his linking of the systematic destruction of the welfare state with the rising tide of authoritarianism. 
The next section briefly reviews the introduction of New Public Management into public services in the UK, Sweden and elsewhere to demonstrate how the welfare state has changed and its role diminished under neoliberal governance.

\section{Major shifts in public policy under neoliberal ideology}

New Public Management, which introduced business methods to deliver public services in the UK and other developed countries from the 1980s and throughout the 1990s, signalled a sharp shift in favour of the market. Conservative governments in Europe and elsewhere adopted neoliberal economics (Scott-Samuel et al., 2014). Their strong commitment to property rights, individual freedom, and personal responsibility prompted them to introduce various forms of competition in order to devolve the state's responsibility for its most vulnerable individuals and to enable the privatization of public services (Krachler \& Greer, 2015). This shift challenged the principle of state responsibility for ensuring comprehensive welfare provision for all who need it. It also signified a stark departure from reliance, by all mainstream parties across the political spectrum, on public policy as a means for social transformation (Fotaki, 2011). In addition to privatizing services and tightening eligibility criteria, coupled with various measures for intrusive surveillance (see e.g., Rizq, 2013), it promised users freedom of choice over types of services and how they are provided, to promote service user empowerment and autonomy.

As I have argued elsewhere in the context of healthcare policy (Fotaki, 2014) and social care (Fotaki \& Boyd, 2005), in many countries, user autonomy and patient-centred care (Fotaki, 2020), to be achieved through market competition, increasingly occupy more prominent positions than equity of access and universalism on policy makers' agendas. However, rather than creating the conditions necessary to empower citizens as co-producers of services, these shifts create responsibilized users who are increasingly expected to deal on their own with issues of ill health, with little or no control over the services from which they are expected to 'choose' (Fotaki, 2011). Crucially, this also means that individual users must navigate the informational maze and monitor the quality of marketized services, irrespective of their ability to do so. Making users and patients responsible for their illnesses or disabilities, and health status an issue of lifestyle and choice also signifies refusal to accept the crucial effect of social inequalities on health outcomes (Fotaki, 2010a; Arcaya et al., 2015; Dorling, 2015). The implicit objective of commodifying all services previously state-provided as benefits was to 'get the needy involved in providing their own security' (Offe, 2018). UK Prime Minister Margaret Thatcher's oft-cited statement opposing all those who 'are casting their problems at society' encapsulates this:

And, you know, there's no such thing as society. There are individual men and women and there are families. And no government can do anything except through people, and people must look after themselves first. It is our duty to look after ourselves and then, also, to look after our neighbours (Keay, 1987). 
Hence, the real and ultimate aim of introducing consumerism into public health services was to promote user choice by removing the notion of dependency on others, or in other words to individualize risks over which one has little choice that are ever-present in capitalist economies (such as economic boom and bust), and to shift responsibility for one's predicament when ill to atomized patients rather than the health system. This is achieved through attacks on relationality and our links with one another, and on the welfare state, which is a societal arrangement embodying this collective responsibility. Further, neoliberal ideology, and its successful metastasization from finance and economic governance into all walks of life, are underpinned and held together by a set of fantasmatic constructs, among which the fantasy of the consumer as free and unencumbered occupies a central position (Fotaki, 2019a). Consumerism has replaced the notion of dependency while precariousness is evaded. The late capitalist subjects must continuously evade precariousness as an undesirable and unbecoming condition to survive the neoliberal assault on the welfare state. Denial of vulnerability which necessitate reliance on others, is therefore indispensable for this ideology to work effectively on individual subjectivities.

Max Haiven (2014) explains that this is a result of a wider trend whereby popular culture and everyday life are being transformed by the logic of financial capital, which depends on such transformations in the realms of social action, representation, and subjectivity. In the brave neoliberal world there is no need for care, other than as a service or commodity to be bought and sold in the marketplace according to individual preferences. This imaginary is beholden to a system of reproducing financialized capitalism, in which everyone performs the entrepreneurial self and comes at significant cost to their health and well-being. If everything is a matter of personal choice and striving to fulfil our own preferences, then all successes and failures are our responsibility alone. Put differently, neoliberal ideology refuses to accept the precarity of life and the human body, ignoring our infinite capacity for injury, and how we all depend on each other for survival (Butler, 2004; 2009; Fotaki, 2019a). This logic has affected all aspects of life in late capitalism, putting an immense pressure on individuals. A time-trend study conducted in 54 countries found that after the 2008 GFC, rates of suicide increased in many European and American countries, particularly amongst men and in countries with higher levels of job losses (Chang et al., 2013), while a steep decline in fertility rates was observed in many advanced economies (Chen et al., 2018).

In short, neoliberalism propagates new types of subjectivity, by modelling people's behaviours on abstract assumptions of self-interested individuals as rational decision makers motivated solely by the need to enact their preferences and maximize utility through acts of consumption in every circumstance and at all times. It ignores not only pre-existing inequalities of birth and geography (Fotaki, 2017b), but also fundamental facts of the human condition that everyone experiences at some point in life, such as disease, frailty, and death (Money-Kyrle, 1971, cited in Fotaki, 2006).

Although this ideological proposition bears little resemblance to most empirical findings in the fields of biology, neurology, and even descriptive psychology (Fotaki, 2010b), it has dark and pernicious consequences for both how we feel about ourselves, 
and how we see ourselves in relation to others. Introducing consumerism as a governing principle of the neoliberal shift in public policy rejects a basic inclination to care for others when they experience distress, unless as an outcome of personal choice and/or an act of charity. This creates a perverse state of mind that often characterizes individuals and groups in corporate life (Long, 2008). Such logic has now colonized areas of public policy that were until recently defined by the notions of care, solidarity, and responsibility for the other, such as health and social care (Fotaki, 2010b), producing toxic attachments that corrupt the institutional and moral fabric of organizations (Long, 1999). The social cost of shifting to individualized consumerism is that it induces a corrupt way of thinking in which any sense of the greater good is sacrificed to fulfilling individual wants.

The worldwide dominance of this paradigm has also drastically altered the terms of debate on collective responsibility for the disadvantaged, and how we should share our resources with them. Distant others, in geographical locales to which the production of most consumerist goods is outsourced, are more often than not seen as difficult to relate to or unrelatable. Global supply chains of transient and cheap migratory labour are essential in enabling late capitalism to continue to produce goods to fuel consumption ad infinitum and fulfil customers' allegedly insatiable desires. Different forms of expulsion described by Sassen (2014) are then seen as unavoidable in feeding this insatiable consumerism, despite creating a growing number of dispossessed in the developing world, who join the ranks of underpaid and disposable labour in developed countries. Various ideological discourses centring on the business logic and efficiency (Fotaki \& Prasad, 2015) are deployed to legitimize this as inevitable, or even desirable, avoiding a basic realization of the interconnectedness and similarities between customers and producers of consumer goods. This allows us to ignore that such goods are produced in unacceptable working conditions, often involving human rights violations. Migrants are centrally implicated in highly precarious work experiences at the bottom end of labour markets in Global North countries, including becoming trapped in forced labour (Lewis et al., 2015). The EU migrant workers moving from Poland to the UK also experience precarious work conditions (Duda-Mikulin, 2019) as various categories of the poor and dispossessed in the capitalist metropolis (Tyler, 2013).

The rapid pauperization and impoverishment of the middle classes in the developed world, who can no longer afford to act as consuming subjects - an ever more pronounced reality since the GFC - creates conditions in which the newly poor may compare themselves with migrants appearing on their doorsteps. This may give rise to hostility, but also solidarity. For when precarity becomes so widespread and random, people may choose to collaborate and care for each other. Humans are wired to cooperate on a larger scale than most other mammals, and since the time of foraging societies, people have regularly cooperated with many unrelated individuals (Boyd \& Richerson, 2009). In times of crisis, 'rather than press for maximum advantage, people look out for one another' (Sandel, 2009, p. 7).

To prevent the latter outcome, the neoliberal ideology of individualism and personal responsibility divides the dispossessed and the new poor in developed capitalist countries 
from the refugees and forced migrants of the global South who are constituted as undesirable and abject. This is why the precarity to which populations are increasingly exposed in developed economies, including affluent European countries, is evaded or projected onto less fortunate others (Fotaki, 2019a). Various ideologies of 'othering' are mobilized to maintain the illusion of security for the not-yet dispossessed. These ideologies work performatively, as they are stitched and held together by affective attachments to desirable states of being. Such is for instance the notion of a customer as sovereign and free to choose in order to satisfy her 'unlimited' individual wants.

The analysis now turns to the feminist philosophy of Judith Butler to explain the idea of the performativity of discourse, and the deployment of affect as an inherent aspect of performativity. Butler's ideas demonstrate how the discursive construction of 'otherness' operates in macro-level political pronouncements, and how it can be counteracted by drawing productively on the idea of precarity, through relationality discussed in the next section. Specifically, a concept of ethical responsibility as intersubjective relationality is developed, which ensures the survival of the unknown 'other'. This is achieved by building on Butler's psychosocial theorization of the subject's formation through recognition in social symbolic order (Butler, 1990, 1993), and her theoretical framing of precarity as a fundamental condition defining sociality (Butler, 2004, 2009). The proposed theoretical lens then links various levels of analysis to illuminate processes through which powerful influences may affect responses to other people's vulnerability and helplessness (Fotaki, 2017b).

\section{Relationality as policy protecting refugees and forced migrants}

The idea of relationality offered here is a foundational concept in feminist thinking which has also been productively applied in other disciplines such as management education for instance (see Fotaki \& Prasad, 2015). According to Judith Butler (1990, 1993), relatedness and relationality is the foundation of subjectivity and of our very existence: to be fully human is to be recognized by others, giving meaning to our individual experiences and transforming us into social beings (Butler, 2004). In a sociological reiteration of her thesis, Bauman (2016, p. 34) asserts that the all-threatening and imminent withdrawal of public recognition is reflected in the individual's diminution of self-respect.

The individual's desire for recognition in the symbolic order, which Butler proposes by drawing on Hegelian philosophy and psychoanalytic theory, is helpful for explaining how our own precarity binds us to others (Butler, 2004). It is in relation to literal others (loved ones) and symbolic others (community, nation, etc.) that we strive to remake the world that surrounds us when we engage in political activities (Fotaki, 2010b). Butler elucidates how we all depend on the other under conditions that are inevitably precarious, and how fears about our own survivability link us with others whom we do not know (Butler, 2004, 2009). She takes inspiration from Emmanuel Lévinas, regarding the face of the other belonging to the sphere of ethics, in positing that our infinite capacity for being injured obliges us to protect the other. This is not about identification based on empathy, but 
about relationality as an ethical obligation toward the irreducible other. Butler argues that since we all depend on the other within conditions that are inevitably precarious, our fears about survivability link us to others we do not know (Butler, 2004). In other words, the existence of the other is a precondition for our own literal and symbolic survivability: "who "I" am is nothing without your life, and life itself has to be rethought as this complex, passionate, antagonistic, and necessary set of relations to others' (Butler, 2009, p. 44). It is our own vulnerability, which we all share as humans, that makes us infinitely open to injury and precariousness in the absence of collective solutions. At the same time, 'precarity' designates the politically induced condition that causes some populations to suffer from failing social and economic networks of support and become differentially exposed to injury, violence, and death (Butler, 2009).

Yet the face of the other, in its defencelessness and precarity, is at once a call to kill and a call for peace (Benjamin, 2004). This is expressed in a tendency to turn 'others of difference' into 'others of opposition' (Chang, 2008), often provoked by lack of familiarity with 'the Other'. Such unfamiliarity may lead to constructions of the Other 'in the mind' (Armstrong, 2005), a misperception that creates 'artificial' distance between refugee groups and host citizens, which is entertained by all parties involved. This is often harder to overcome than physical distance. Thus, 'Us and Them' dynamics form a substantial part of the everyday life experiences of both refugees and host citizens.

Under neoliberalism, therefore, we are witnessing a rapid increase in various categories of undeserving 'others', such as the new poor in affluent Western societies, who are pitted against dispossessed refugees and forced migrants from the developing world to compete relentlessly under conditions of induced scarcity and ever-increasing precarity. Excluded others are seen as absolute 'monstrous others', and as people with no human rights worth protecting. Disregard for humanitarian principles is predicated on radical inequality between lives that are worth living and protecting, and unworthy deaths that are unseen and unmarked by grieving (Butler, 2004, 2009).

New insights from feminist thinking offered by Bracha Ettinger (2006) extend Butler's ideas by proposing an ethics of 'difference', which is based on connectedness, co-existence, and compassion toward the other, grounded in our corporeal and embodied relationships. Ettinger re-theorizes subjectivity as co-emergent through encounters with an unknown other, presenting a compelling ethical proposition that connects Lévinasian responsibility for the other with feminist thought of the other defined as 'becoming together'. A relational reconsideration of subjectivity vis-à-vis the other has implications for care. Caring and relating thus share conceptual and ontological resonance (Puig de la Bellacasa, 2012).

This reconsideration, it is argued, can produce a new social imaginary which opposes the neoliberal conception of 'care' as a marketized good that operates at the level of normative abstractions when referring to live human beings. Such disembodied conjectures do not conceive of persons from the inside, and cannot understand them, care about them, or assess their moral character, as even Adam Smith, father of economics, advocated (Collier, 2018). Our shared and embodied notion of vulnerability may be useful in reframing the 'migration issue' from an abstract global debate into something 
that resonates in people's lives, thus challenging the perception of the refugee as an unrelatable 'other'. It stresses the need to produce new representations notion of the subject as socially constituted through their relations with others to overturn this limited notion. This will require systematic and sustained interventions in the discursive space, with the aim of denaturalizing the anti-migration rhetoric and giving new meaning to many established assumptions.

Yet care for the other is political, as it implies distributing resources, and asking broader social and political questions to contextualize caring within them (Tronto, 1993), such as who benefits from such care relationships and who provides care. It is thus important not to rely simply on people's ethical values, but to promote policies and politics that account for our shared precariousness and the uncertainty we all face under the neoliberal regime. Such a re-positioning of responsibility for the other has important implications for understanding and rethinking developments in public policy (Fotaki, 2017b). It urges us to make the role of governments explicit in how people understand, treat, and relate to one another, and to explain why public policies must emerge from a recognition that all our lives are precarious, and that we all depend on society for survival.

\section{Conclusion}

It has been argued in this article that we must protect the dispossessed within and outside our borders because their fate concerns us all. We must value their lives as equal and accept their vulnerability as our own. Public and social policies in particular, are key in helping us to recognize this, and to realize that we all depend on each other for survival. As fear displaces compassion, and Europeans become influenced by a discourse of racialized 'others' posing a threat to national security, national identity, and the stability of their welfare systems, better understanding how solidarity initiatives with refugees arise and what makes them successful may be particularly important to counteract these developments. Paraphrasing and appropriating Olga Tokarczuk's (2019) reference to 'tenderness' - in her Nobel Prize acceptance speech — as a way being in the world, this will require a sustained focus on 'the bonds that connect us, the similarities and sameness between us', to re-envision policy and politics as 'a way of looking that shows the world as being alive, living, interconnected, cooperating with, and codependent on itself'.

\section{References}

Aiyar, S., Barkbu, B., Batini, N., Berger, H., \& Detragiache, E. (2016). The refugee surge in Europe: Economic challenges. IMF staff discussion note SDN/16/02, International Monetary Fund, Washington, DC.

Amnesty International (2015). Volunteers help refugees survive while Europe's leaders still search for solutions. Amnesty International [website], 21 September. https://www. 
amnesty.org/en/latest/campaigns/2015/09/volunteers-help-refugees-survive-whileeuropes-leaders-still-search-for-solutions/

Arcaya, M. C., Arcaya, A. L., \& Subramanian, S.V. (2015). Inequalities in health: definitions, concepts, and theories. Global Health Action, 8. https://doi: 10.3402/gha.v8.27106

Arcimaviciene, L., \& Baglama, S. H. (2018). Migration, metaphor and myth in media representations: The ideological dichotomy of 'them' and 'us'. Sage Open, 8(2). https:// doi: $10.1177 / 2158244018768657$

Arenaidé (2017). Welcoming refugees: Local European experiences. Report from the conference held in Norrköping 25-27 January 2017. https://arenaide.se/wp-content/uploads/ sites/2/2017/01/conference-report-welcoming-refugees-local-european-experiences.pdf Arendt, H. (1976/1951). The origins of totalitarianism. Harcourt Brace Jovanovich.

Armstrong, D. (2005). Organization in the mind: Psychoanalysis, group relations and organizational consultancy. Karnac Books.

Bauman, Z. (2016). Strangers at our door. Polity Press.

BBC (2017). The Greek island where Syrian refugees are welcome. BBC News, 12 July. https://www.bbc.co.uk/news/av/world-europe-40586229/the-greek-island-where-syrianrefugees-are-welcome

Benjamin, J. (2004). Beyond doer and done to: An intersubjective view of thirdness. Psychoanalytic Quarterly, 73(1), 5-46.

Berry, M., Garcia-Blanco, I., \& Moore, K. (2015). Press coverage of the refugee and migrant crisis in the EU: A content analysis of five European countries. Report prepared for the United Nations High Commission for Refugees. https:/www.unhcr.org/56bb369c9.pdf

Betts, A. (2010). Survival migration: A new protection framework. Global Governance, 16(3), 361-382.

Boyd, R., \& Richerson, P. J. (2009). Culture and the evolution of human cooperation. Philosophical Transactions of the Royal Society B: Biological Sciences, 364(1533), 3281-3288.

Butler, J. (1990). Gender trouble: Feminism and the subversion of identity. Routledge.

Butler, J. (1993). Bodies that matter: On the discursive limits of 'sex'. Routledge.

Butler, J. (2004). Precarious life: The powers of mourning and violence. Verso.

Butler, J. (2009). The frames of war. Verso.

Canal, G. (2017). Refugees brought this small, dying Italian village back to life. Global Citizen, 19 April. https:/www.globalcitizen.org/en/content/refugees-brought-this-smalldying-italian-village/

Castles, S. (2003). Towards a sociology of forced migration and social transformation. Sociology, 37(1), 13-34.

Castles, S., \& Miller, J. M. (2009). The age of migration: International population movement in the modern world (4th ed.). Palgrave MacMillan.

Chang, H. (2008). Autoethnography as method. Left Coast Press.

Chang, S.-S., Stuckler, D., Yip. P., \& Gunnell, D. (2013). Impact of 2008 global economic crisis on suicide: Time trend study in 54 countries. British Medical Journal, 347. https:// doi:10.1136/bmj.f5239 
Chen, W., Mrkaic, M., \& Nabar, M. (2018). Lasting effects: The global economic recovery 10 years after the crisis. IMF Blog, 3 October. https://blogs.imf.org/2018/10/03/lastingeffects-the-global-economic-recovery-10-years-after-the-crisis/

Cholewinski, R., \& Taran, P. (2009). Migration, governance and human rights. Refugee Review Quarterly, 28(4), 1-33.

Cieślińska, B. (2017). Hospitality and the migration crisis. Rocznik Teologii Katolickiej, 16, 93-110.

Cieślińska, B., \& Dziekońska, M. (2019). The ideal and the real dimensions of the European migration crisis: The Polish perspective. Social Sciences, 8(11), art. 314. https:// doi:10.3390/socsci8110314

Collier, P. (2018). The future of capitalism: Facing new anxieties. Allen Lane.

Coppola, F. (2018). The greatest depression. Forbes, 31 July.

D’Albis, H., Boubtane, E., \& Coulibaly, D. (2018). Macroeconomic evidence suggests that asylum seeks are not 'a burden' for Western European countries. Science Advances, 4(6). https://doi:10.1126/sciadv.aaq0883

Dempster, H., \& Hargrave, K. (2017). Understanding public attitudes towards refugees and migrants. ODI Working Paper 512, Overseas Development Institute, London.

Dennison, J., \& Dražanová, L. (2018). Public attitudes on migration - Rethinking how people perceive migration: An analysis of existing opinion polls in the Euro-Mediterranean region. Migration Policy Centre, European University Institute.

Dorling, D. (2015). Inequality and the 1\%. Verso.

Duda-Mikulin, E. A. (2019). EU migrant workers, Brexit and precarity. Polish women perspectives from inside the UK. Bristol University Press.

Esses, V., Hamilton, L. K., \& Gaucher, D. (2017). The global refugee crisis: Empirical evidence and policy implications for improving public attitudes and facilitating refugee resettlement. Social Issues and Policy Review, 11(1), 78-123.

Ettinger, B. L. (2006). The matrixial borderspace (essays from 1994-1999). University of Minnesota Press.

Fine, S. (2019). All at sea: Europe's crisis on solidarity for migration. Policy Briefing, European Council on Foreign Relations, 14 October. https://www.ecfr.eu/publications/summary/all_at_sea_europes_crisis_of_solidarity_on_migration

Fotaki, M. (2006). Choice is yours: A psychodynamic exploration of health policy making and its consequences for the English National Health Service. Human Relations, 59(12), 1711-1744.

Fotaki, M. (2010a). Equity and choice in health care: Can they go hand in hand? Theory and evidence. Sociology of Health \& Illness, 32(6), 898-913.

Fotaki, M. (2010b). Why do public policies fail so often? Exploring health policy making as an imaginary/symbolic construction. Organization, 17(6), 703-720.

Fotaki, M. (2011). Towards developing new partnerships in public services: Users as consumers, citizens and/or co-producers driving improvements in health and social care in the UK and Sweden. Public Administration, 89(3), 933-955. 
Fotaki, M. (2014). Can consumer choice replace trust in the National Health Service in England? Towards developing an affective psychosocial conception of trust in health care. Sociology of Health \& Illness, 36(8), 1276-1294.

Fotaki, M. (2016). Outsourcing a humanitarian crisis to Turkey — is that the European thing to do? The Conversation, 9 March. https://theconversation.com/outsourcing-ahumanitarian-crisis-to-turkey-is-that-the-european-thing-to-do-55915

Fotaki, M. (2017a). TEDx talk: Turning fear to purpose. TEDxVlerickBusinessSchool [video]. https://www.youtube.com/watch?v=-aP_Ug11La4

Fotaki, M. (2017b). Relational ties of love: A psychosocial proposal for ethics of compassionate care in health and public services. Psychodynamic Practice, 23(3), 181-189.

Fotaki, M. (2019a). Relationality in the age of neoliberal dispossession: Protecting the other. In U. Lewin and A. Zajenkowska (eds.), Europe on the couch (Ch. 3). Routledge.

Fotaki, M. (2019b). A crisis of humanitarianism: Refugees at the gates of Europe. International Journal of Health Policy and Management, 8(6), 321-324.

Fotaki, M. (2020). Choosing providers. In E. Nolte, S. Merkur, \& A. Anell, (eds.) Placing the person at the centre of the health system: Learning from innovation and best practice. (Ch. 8) (201-227). WHO European Observatory. Cambridge University Press.

Fotaki, M., \& Boyd, A. (2005). From plan to market: A comparison of health and old age care policies in the UK and Sweden. Public Money \& Management, 25(4), 237-243.

Fotaki, M., \& Prasad, A. (2015). Questioning neoliberal capitalism and economic inequality in business schools. Academy of Management Learning \& Education, 14(4), $556-575$.

Gogou, K. (2017). The EU-Turkey deal: Europe's year of shame. Amnesty International [website], 20 March. https://www.amnesty.org/en/latest/news/2017/03/the-eu-turkey-deal-europes-year-of-shame/

Hainmueller, J., \& Hopkins, D. J. (2014). Public attitudes toward immigration. Annual Review of Political Science, 17, 225-249.

Haiven, M. (2014). Cultures of financialization: Fictitious capital in popular culture and everyday life. Palgrave Macmillan.

Haque, M. S. (2001). The diminishing publicness of public service under the current mode of governance. Public Administration Review, 61, 65-82.

Hein, J. (1993). Refugees, immigrants and the state. Annual Review of Sociology, 19, 43-59.

Hunter, P. (2016). The refugee crisis challenges national health care systems. EMBO Reports, 17(4), 492-495.

Huntington, S. P. (1993). The clash of civilizations? Foreign Affairs, 72(3), 22-49.

International Migration Office (2020). Flow monitoring in Europe. https://migration.iom. int/europe?type $=$ arrivals

Jaskułowski, K. (2019). The everyday politics of migration crisis in Poland: Between nationalism, fear and empathy. Palgrave.

Karakayali, S. (2018). The Flüchtlingskrise in Germany: Crisis of the refugees, by the refugees, for the refugees. Sociology, 52(3), 606-611.

Keay, D. (1987). Interview with Margaret Thatcher. Woman's Own, 23 September. 
King, R., \& Lulle, A. (2016). Research on migration: Facing realities and maximising opportunities - a policy review. European Commission. http://ec.europa.eu/research/social-sciences/pdf/policy_reviews/ki-04-15-841_en_n.pdf

Konat, G. (2019). How Poland's failed transition fed the nationalist right. JacobinMag, 11 April. https://www.jacobinmag.com/2019/11/poland-law-justice-party-pis-austerityneoliberalism

Krachler, N., \& Greer, I. (2015). When does marketisation lead to privatisation? Profit-making in English health services after the 2012 Health and Social Care Act. Social Science \& Medicine, 124, 215-223.

Krzyżanowska, N., \& Krzyżanowski, M. (2018). 'Crisis' and migration in Poland: Discursive shifts, anti-pluralism and the politicisation of exclusion. Sociology, 52(3), 612-618.

Krzyżanowski, M. (2018). We are a small country that has done enormously lot: The 'Refugee Crisis' and the hybrid discourse of politicizing immigration in Sweden. Journal of Immigrant \& Refugee Studies, 16(1-2), 97-116.

Legrain, P. (2016). Refugees work: A humanitarian investment that yields economic dividends. Open Political Economy Network, 18 May. http://www.opennetwork.net/refugeeswork/

Lewis, H., Dwyer, P., Hodkinson, H., \& Waite, L. (2015). Hyper-precarious lives: Migrants, work and forced labour in the Global North. Progress in Human Geography, 39(5), $580-600$.

Long, K. (2012). In search of sanctuary: Border closures, 'safe' zones, and refugee protection. Journal of Refugee Studies, 26(3), 458-476.

Long, K. (2013). When refugees stopped being migrants: Movement, labour and humanitarian protection. Migration Studies, 1(1), 4-26.

Long, S. (1999). The tyranny of the customer and the cost of consumerism: An analysis using systems and psychoanalytic approaches to groups and society. Human Relations, 52(6), 723-743.

Long, S. (2008). The perverse organization and its deadly sins. Karnac.

Łaciak, B., \& Segeš Frelak, J. (2018). The wages of fear: Attitudes towards refugees and migrants in Poland. Foundation Institute of Public Affairs/Fundacja Instytut Spraw Publicznych.

Maccanico, Y., Hayes, B., Kenny, S., \& Barat, F. (2018). The shrinking space for solidarity with migrants and refugees: How the European Union and member states target and criminalize defenders of the rights of people on the move. Transnational Institute. https:// www.tni.org/files/publication-downloads/en_theshrinkingspace.pdf

Malkki, L. H. (1995). Refugees and exile: From 'refugee studies' to the National Order of Things. Annual Review of Anthropology, 24, 495-523.

Malkki, L. H. (1996). Speechless emissaries: Refugees, humanitarianism and dehistoricization. Cultural Anthropology, 11(3), 377-404.

McHugh-Dillon, H. (2015). If they are genuine refugees, why? Public attitudes to unauthorised arrivals in Australia. Foundation House. 
Money-Kyrle, R. (1971). The aim of psychoanalysis. In D. Meltzer (ed.), The collected papers of Roger Money-Kyrle (Ch. 33). Clunie Press.

Nilsson, P. (2018). Opening the door to the far right. Jacobin Magazine, 9 October. https:// www.jacobinmag.com/2018/09/sweden-election-sap-sweden-democrats-immigrationfar-right

Offe, C. (2018). Democracy can't survive without the welfare state: An interview with Maya Razmadze. Jacobin Magazine, 16 December. https:/www.jacobinmag.com/2018/12/ offe-work-society-capitalism-jobs-welfare-sharing-economy

Papademetriou, D. G., \& Banulescu-Bogdan, N. (2016). Understanding and addressing public anxiety about immigration. Migration Policy Institute.

Puig de la Bellacasa, M. (2012). 'Nothing comes without its world': Thinking with care. Sociological Review, 60(2), 196-216.

Rea, A., Martiniello, M., Mazzola, A., \& Meuleman, B. (eds.) (2019). The refugee reception in Europe. Polarized opinions and mobilizations. Éditions de l'Université de Bruxelles.

Reinisch, J. (2015). History matters ... But which one? Every refugee crisis has context. History \& Policy, 29 September. http:/www.historyandpolicy.org/policy-papers/papers/ history-matters-but-which-one-every-refugee-crisis-has-a-context

Rizq, R. (2013). States of abjection. Organization Studies, 34(9), 1277-1297.

Sandel, M. (2009). Justice. What is the right thing to do? Penguin Books Ltd.

Sassen, S. (2014) Expulsions: Brutality and complexity in the global economy. Belknap Press.

Scott-Samuel, A., Bambra, C., Collins, C., Hunter, D., McCartney, G., \& Smith, K. (2014).

The impact of Thatcherism on and health and well-being in Britain. International Journal of Health Services, 44(1), 53-71.

Taylor, M., Wintour, P., \& Elgot, J. (2015). Calais crisis: Cameron pledges to deport more people to end 'swarm' of migrants. The Guardian, 30 July. https://www.theguardian. com/uk-news/2015/jul/30/calais-migrants-make-further-attempts-to-cross-channel-intobritain

Tokarczuk, O. (2019). Nobel lecture: The tender narrator. The Nobel Foundation, Stockholm, Sweden, 7 December.

Tramontana, F. (2018). Five lessons history can teach us about migration. Warwick Knowledge Centre [website], 24 July. http://warwick.ac.uk/newsandevents/knowledgecentre/ arts/history/migration

Tronto, J. (1993). Moral boundaries: A political argument for an ethic of care. Routledge. Tyler, I. (2013). Revolting subjects: Social abjection and resistance in neoliberal Britain. Zed Books.

UNHCR (1951). The 1951 Refugee Convention. UNHCR. http://www.unhcr.org/1951-refugee-convention.html

UNHCR (2015). Over one million sea arrivals reach Europe in 2015. UNHCR News Stories, 30 December. http://www.unhcr.org/5683d0b56.html

Wadsworth, J., Dhingra, S., Ottaviano, G., \& Van Reenen, J. (2016). Brexit and the impact of immigration on the UK. Centre of Economic Performance, London School of Economics and Political Science. 
WEF (2017). The future of Europe: Comparing public and elite attitudes. World Economic Forum [website], 20 October. https://www.weforum.org/agenda/2017/10/the-future-ofeurope-comparing-public-and-elite-attitudes/

Widmalm, S. (2018). The ideology of economism can explain the rise of right-wing populism in the upcoming Swedish elections. Respons, 3. http://tidskriftenrespons.se/artikel/ ideology-economism-can-explain-rise-right-wing-populism-upcoming-swedish-election/

Acknowledgements

I would like to thank two anonymous referees for their useful comments and Dr Maria Theiss for the invitation to submit this article to the journal. Any remaining errors are my responsibility alone. 